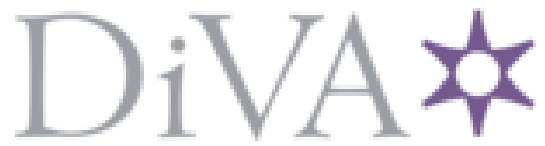

http://www.diva-portal.org

\title{
Postprint
}

This is the accepted version of a chapter published in The Aesthetics and Ethics of Copying.

Citation for the original published chapter:

Bäcklund, J. (2016)

The Paradox of Style as a Concept of Art

In: Darren Hudson Hick, Reinold Schmücker (ed.), The Aesthetics and Ethics of

Copying (pp. 211-223). London: Bloomsbury Academic

N.B. When citing this work, cite the original published chapter.

Permanent link to this version:

http://urn.kb.se/resolve?urn=urn:nbn:se:lnu:diva-92561 


\section{The Paradox of Style as a Concept of Art}

Jan Bäcklund

I have walked pass this sculptural structure several times and without giving it much thought or any contemplation I have just assumed - subconsciously - that it was the one of many brickworks by Per Kirkeby. For some reason that I don't remember, I came to talk to an artist friend and colleague of mine in the vicinity of the brickwork. He informed me that the sculpture was not a sculpture by Kirkeby, but one created by a professor in architecture. My artist friend was quite upset by the sculpture and told me that he and other artists for a long time without success had tried to convince the schools of architecture to remove the structure, with the argument that it parasitised on Kirkeby's brick sculptures. At a later occasion I recounted this to two theoreticians of architecture, who knew of the maker of the 'Kirkebylike' structure. Not unsurprisingly, they saw nothing in the line of Kirkeby in it, but just, as intented, a piece of architectural research in brick structures of high interest, but unrelated to art. I believe they are right, underlining that the question of stylistic copy or plagiarism is first and foremost related to the developments of the concept of art, that is, the institutions, markets, history and discourses of visual art.

I got the name of the author, but I don't remember it. I could, of course, find it out, but as a crucial part of my argument is that this namelessness - seen from the perspective of visual art -is intrinsically linked with a positive assessment of plagiarism, I will let the author remain anonymous and authorless; had my focus been theory of architecture, I would have looked upon an authored structure, and the subject of my discourse would be fundamentally different. 
Of course there exist a great number of 'stylistic copies' within the field of visual art.

We have all seen them, but we don't remember them, as they linger in the periphery, at inconsequential and local exhibitions, and they never 'get a name', precisely because they are so blatantly embarrassing in their crime against art, in not understanding the first rule of artistic production that you should develop your own uniquely identifiable style. Now, 'artist' is not a protected title, and art is not a static discourse. One of the most dramatic changes in the art world during the last decade has undoubtedly been the inclusion of practices never intended to be seen as art, but in the light of different recent developments suddenly makes perfect sense within the institutions, markets and history of art. Some cases in point would be the inclusion of projects like those of Erkki Kurenniemi, Anton Zeilinger or Korbinian Aigner in the Documenta 13 (2012) or the even more extra-artistically inclusive Biennale di Venezia of 2013, but can be observed in the vast majority of any major trend-mapping exhibition of the 21 st century.

Thus the indignation of my colleague is not only understandable, but furthermore orthodox to our views of art and artistic integrity. As an artist, you may very well copy other artists' works, as appropriation art has demonstrated. This is because appropriation art is another style, however contradictory it may sound. Appropriation is a double signing - 'a Walker Evans by Sherrie Levine' or 'a Warhol by Sturtevant' - and articulates a different artistic enunciation than the work appropriated, even if the works in question are aesthetically or physically indiscernible. As a non-artist, on the other hand, the first rule of artistic creation does not apply and you may - of course - use whatever style you might find appropriate in your extra-artistic project, as for instance our Danish architect, but a project that potentially could be an artistic project, and hence the edgy reaction of an art world which is at the same time inclusive as it is protectionist. 
Technically, we call this unacceptable and non-discursive (as opposed to the acceptance and discursiveness of appropriation art) form of artistic parasitism plagiarism, that is: issuing another's work as your own, in opposition to forgery, which is issuing your own work as another's. My argument here will, on the one hand, be to assess why plagiarism of an artistic style must necessarily be the most embarrassing thing an artist can do, and on the other hand why plagiarism is artistically necessary as well. As the argument is not an ontological one, but a historical one, the paradox proposed here is a question to the future of art.

\section{Image and Style}

An artistic style that can be plagiarised is one that can be the subject of copying. As we know from the studies of Hans Belting (1991) and others, style, as we understand it, was, if not invisible, then at least an unobservable during late Middle Ages. This invisibility can be tested with the help of an example, taken from Alexander Nagel (2004: 104-105), of a painting, brought home to Cambrai from Rome by a Flemish prelature in 1440. This was a Madonna and Child attributed to St. Luke - not necessarily because it was believed that St. Luke himself had conducted the brush, but because it was believed that it was a true and authentic copy, that is, an original image of Our Lady and the Christ Child. When it was painted was irrelevant: the image was authentic. Today we know that the image was painted in the mid-14th century, probably in Siena, in a byzantine style, and even a copy of this type, Virgo Eleousa, was regarded as an original image by St. Luke as well. The CambraiMadonna, in its turn, was copied at least 15 times, among others, by Petrus Christus, Hayne from Brussels, and Rogier van der Weyden. The image was, of course, never signed, as its authority was self-evident, St. Luke being the only one who had ever painted Our Lady. Thus, the copies were as authentic images as their prototype because - as we now know from digital images - there was no such thing as 'an original' and 'a copy'; the copyability being 
an intrinsic property of the image, which the legend of the Mandylion clearly illustrates (see Lenain 2007; Lenain 2011: 74-76, 123-33; Belting 1991: 349-382). On the other hand, it is not at all improbable that no one could see the - for us - obvious stylistical differences between the copies, as there were no observation apparatus to detect any such differences. The question of attribution, the author function, concerned the image, not the style. The authenticity was first and foremost related to the image, not to the indexical traces in matter. Correspondingly, when Alexander Sforza had an image of Madonna and Child copied with the inscription: 'These had Saint Lucas painted in the living (in vivo). The painting is the authentic portrait (propria effigies). Alexander Sforza gave the commission, Melozzo has painted it. Lucas would say it would be his own work (diceret esse suam)' (Belting 1991: 382). The authenticity or originality of the painting is altogether related to the image (Lucas Painting Our Lady) and the authority of issuing (Alexander Sforza), not at all in the painting of it or any painterly style, as Luke still would recognise it as his own work.

During the early modern period, style became a predominantly normative or qualitative concept like Vasari's distinction between disegno and colour, or like the later distinction between antique or modern, or between the beautiful or the sublime. This qualitative and normative concept of style was also the reason why the practice of copying became paramount in any artistic training. The concept of imitatio was not so much related to the motive, as to the normative style of the fine arts. This concept is especially obvious with the Musée des Études, a collection of copies established 1834 within the École des BeauxArts with the purpose of instructing students in the work of the classical masters. It was this museum that inspired Charles Blanc for his Musée des Copies, a project which, however, failed immediately after its realization in 1873. The art historian Albert Boime laconically notes, in an article from 1964 on La Musée des Copies, 'that the favorable attitude towards the copies produced for the Musée des Études was expressed a year before the Revolution of 
1848; by 1871 it will have been completely reversed. The loss of the Ecole's grip over the national art and the undermining of academic training discredited the essential value of copies' (Boime 1964: 237).

The revolutions of Manet and Courbet, together with the advent of art history as an academic discipline, have been two important factors in this reversal of values, and I will return to them, but I believe that the effects of one incident especially have been underestimated in relation to this reversal of values. I am thinking about the Bastianini-affair which emerged with the Louvre's spectacular acquisition of a Renaissance portrait bust in January 1866 for the enormous sum of 14,000 French Francs. In comparison the French state had paid 6,000 French Francs for Venus de Milo in 1820. The sculpture had been exhibited in Paris a year before and there caused a lot of excitement as a masterpiece of Renaissance art. After a heated debate it finally turned out that the sculpture was not by Donatello, Mino da Fiesole, Desiderio Settignato or by any other early Renaissance artist, but a modern product by the Florentine sculptor Giovanni Bastianini. In the aftermath of the passionate debates between Italian and French art historians, it turned up that Bastianini had produced a number of portrait busts in an Early Renaissance style (see Moskowitz 2004, 2006; Warren 2005).

Since then Bastianini is used as a case amongst other in the annals of art forgery, but it can be argued, as Anita F. Moskowitz does, that more than being a case amongst other, the Bastianini case marked a paradigmatic shift in our qualifications of images. During the $1850 \mathrm{~s}$ and 1860s, Bastianini produced and exhibited such portrait busts under his own name, although they were not signed (Moskowitz 2004: 169). They are indeed made in an antique style and artificially aged. But this was wanted by the buyers and a not-uncommon practice by a number of Italian sculptors since the Renaissance all the way up to the 20th century, as the later parallel case with Alceo Dossena demonstrates. Dossena was in 1928 exposed as the forger behind a number of antique, medieval and early modern works and since archived in 
the shameful dossiers of art forgery (see Sox 1987), but his 'legitimate' work operates with the same modus as those now considered fake as a half-length marble bust of Minerva Tarquinio Maiullo (1889-1973) commissioned by her father illustrates. Not only does she pose "in a carefully articulated costume of square-necked dress and pendant necklace in the Italian Renaissance style" of Antonio Rosselino or Benedetto da Maiano (Darr et al. 2002: vol. 2, 120), mixed with a more contemporary and loose way of carving the hair, but the surface of the marble is artificially tinted to give the bust an antique appearance. Nevertheless it is signed 'ROMA - ALCEO DOSSENA' on the front left part of the base.

Thus, rather than a forger, one could argue that Bastianini, Dossena and this tradition practised a kind of stylistic remembrance, or a physical immanent linking, of different persons and subjects through a stylistic glue. It was rather the meeting of the Italian tradition of sculpture as a traditional craft with the emerging new paradigm of art, which in the $1860 \mathrm{~s}$ caused the confusion on the Parisian art market where authenticity for the one became forgery for the other. For Bastianini, the image was a true portrait made in a customary, that is, impersonal and continuous, style.

For the emerging art world in Paris, operating with the new 'art historical hanging' at the Louvre, and a chronotopological plotting of the history of art, Dossena's bust was a modern fake in adopting a style not congruent with its chronotopological origin. The dispute whether Bastianini's or Dossena's productions are fakes is unfortunately blurring the question. The crux of the conflict is the question of the identity of style. To put it bluntly: the iconoclasm of modernism is the replacement of images with the avant-garde of individual styles. With Courbet, Manet, and the emergence of modernist art, the significance of art images made its final shift from a question of iconic veracity to a question of a discreet - that is, well-defined - stylistic identity. Arguably, Eduard Manet and Gustave Courbet were the first artists who copied motives (images) in a ostensible different style - in Courbet's case, in 
the reference to Vélasquez in his Artist's Studio, and, in Manet's case, in references to Tizian/Giorgione with La Déjeuner and Olympia. In both cases the method is heavily dependent on the visibility - and hence discernability - of the originals in public museums, which thus disrupts the flow of historical styles as a continuous tradition with its variation of an invariance to an anachronistic re-enactment. This is especially obvious if one compares Manet's early copy of Venus of Urbino, which is perfectly in concordance with the premodern notions of artistic training through (stylistic) imitation, and Charles Blanc's motivation for a Musée des Copies with Olympia, where Manet uses a well-known motive to differentiate his own uniquely identifiable style. The stylistic discernability thus becomes an image of a second order. It is not the first order image (Cézanne's apples or Van Gogh's landscapes) that is recognised as such, but the work's being immediately recognizable as 'a Cézanne' or 'a Van Gogh'.

Neither is there any coincidence that the Bastianini-affair took place simultaneously with the emergence of art history as an academic discipline of which connoisseurship and attribution constituted the foundation and where the discernability of individual and chronotopological style became the values and arguments which made up the art historical discourse. When style during the 19th century became an art historical terminus it also lost its normative and qualitative implications. Now style was used to identify and attribute works to individuals in an art historical, chronotopological grid. When an art work thus became (historically) defined as, for instance, 'French 17th century', this identification was (art historically speaking) more fundamental than a description of what was depicted on the canvas or carved in marble. Attribution is a certain type of observation, an apparatus specifically calibrated to disregard the image for instead to search for traces and indices of its historical origin. 
The confusion caused by the Bastianini-affair is a confusion between this aesthetic non-locality and non-identity on the one hand, and the new art historical attributionism, on the other, with its focus on discrete indexicalities - or the paradigm of trace, as Thierry Lenain calls it with reference to Carlo Ginzburg (Lenain 2011).

The consequences of this shift became even more apparent when the art world moved to New York. The painters of abstract expressionism were typically producing one and the same image over and over again, which can then be distributed to virtually every museum around the world in accordance with Alfred Barr Jr.'s principle of museological art collecting under the dictum of 'one-of-each'. Now, the iconic invisibility of modern iconoclasm is totally eclipsed under the veil of the individual trademarked style. This style is named. We are immediatelly aware of what a Pollock, a Morris Louis, a Jasper Johns looks like, and we know equally perfectly well what a Gerhard Richter, a Sigmar Polke, a Joseph Beuys or a Gotthard Graubner looks like, even though most artists adopt in different genres or styles. That is, one style is always linked to one and only one individual, but any individual can be linked to one or more styles. Again, appropriation art is the recognition of this trademarked style's function as an image and as structurally identical to a subject matter. The concept of 'likeness' (eikon) became, during Modernism, transformed from the deep structure of a subject matter to the flat surface structure of stylistic signifiers.

The purpose of first-order images, be it within or without an art context, has always been to make the absent present, hence images are intrinsically representational, and there is no such thing as a non-representational image. And if - as I believe - artworks since the late 19th century have been producing images of a second order - that is, traces and indices readable as an individual style - what, then, do they represent?

Here one could take a pessimistic stance and conclude that they represent the very close-circuit of the art world between a relic and a proper name, containing as much intrinsic 
value as a bank note, which a number of art critics have done during the last decades (see, e.g., Kuspit 2004; Clair 1988). But I believe there is something more fundamental going on here, and that we have witnessed a paradigmatic change in our representational device, best described by Lev Manovich in his essay 'The Database as a Symbolic Form' (Manovich 2001), the title of course deliberately (and explicitly) playing on Erwin Panofsky's 'Die Perspektive als symbolische Form'. The argument is, to put it crudely, that paradigm takes precedence over syntagm, database takes precedence over narrative, and consequently algorithm takes the place as the representational device instead of linear perspective.

This makes immediate sense when we look on minimal or conceptual art. But it is precisely the algorithmic character of style as an image of the second order which makes it possible for the contemporary Chinese painter Zhang Hongtu to produce images of 'a Cézanne' or 'a Van Gogh' above one of the icons of Chinese ink painting, Fan Kuan's Wanderers by Streams and Mountains from the early 11th century. In China, style has always been copied and subject for art theoretical discourse with a highly sophisticated conceptualisation far beyond to what has been the case in the West. On the other hand, Chinese ink painting consists of a very narrow spectrum of images (typically mountains, bamboos or plum blossoms) whereas the represented image was the parameter of originality in the West. The precise observation in Zhang Hongtu's many paintings of this type lies in the reversing of likeness and style between West and East. It would thus not have been possible to make Fan Kuan's Wanderers in the style of Poussin or Caspar David Friedrich (we wouldn't be able to observe the Poussin or Friedrich part of the superposition), nor would it be possible to make one - for instance - of Picasso's reclining nudes in the style of any Chinese painter, as we wouldn't be able to identify the image as Picasso's. By the same logic we note that making Cézanne's apples in the style of Van Gogh is as impossible as making a Pollock in the style of Mark Rothko. 
Style, as an image of a second order, then, is the representation of a proper name where the proper name carries with it connotations of much the same type as earlier motives did when paintings and sculptures didn't need titles: 'Madonna and Child Enthroned', 'Rest on the Flight to Egypt', 'Portrait of an Old Man', 'Venus and Amor', 'View over Naples' or whatever was depicted on the painting. The shift happens when titles become necessary to explain what is no longer self-evident and when signatures disappear because they have become redundant as it is smeared out all over the picture plane, or, as Michel Foucault famously phrased it:

It would seem that the author's name, unlike other proper names, does not pass from the interior of a discourse to the real and exterior individual who produced it; instead, the name seems always to be present, marking off the edges of the text, revealing, or at least characterizing, its mode of being. The author's name manifests the appearance of a certain discursive set and indicates the status of this discourse within a society and a culture. It has no legal status, nor is it located in the fiction of the work; rather, it is located in the break that founds a certain discursive construct and its very particular mode of being (Foucault 1984: 107-108).

\section{Style and Code}

The consequence of this shift, beginning already in the second half of the 19th century, has surprisingly enough remained largely unnoticed within the Western concept of art, but I believe the inherent paradox became sharply exposed in the aftermath of the controversial 
selling of Count Giuseppe Panza's collection of minimalist and conceptual art to the Guggenheim Foundation in 1990. This transaction raised a number of concerns in the art world on the role of the museum, including deaccessioning and the originality of the physical object.

For the conceptual and minimal artists of the 1960s and 1970s it had became clear that the artistic style and identity was of an algorithmic character and concept art just took the consequence of this matter of fact. What produced 'a Rothko', 'a Pollock' or even 'a Van Gogh' was a processural code of execution. In his 'Paragraphs on Conceptual Art' from 1967, Sol LeWitt wrote: 'In conceptual art the idea or concept is the most important aspect of the work. When an artist uses a conceptual form of art, it means that all of the planning and decisions are made beforehand and the execution is a perfunctory affair. The idea becomes a machine that makes the art' (LeWitt 1999: 12). This method is maybe most clearly illustrated in Lawrence Weiner's practice of stating the algorithm as the title of the work, as, for instance, 'A SQUARE REMOVAL FROM A RUG IN USE' or 'THE RESIDUE OF A FLARE IGNITED UPON A BOUNDARY', all pieces followed by the statement of intent:

1. The artist may construct the piece.

2. The piece may be fabricated.

3. The piece need not be built.

Each being equal and consistent with the intent of the artist the decision as to condition rests with the receiver upon the occasion of receivership (Siegelaub 1969: f.12).

Many years later Alexander Galloway saw very clearly that conceptual art is nothing but a type of code for artmaking, an algorithmic process. 'Code', he wrote in 2002, 'draws a line between what is material and what is active, in essence saying that writing (hardware) cannot do anything, but must be transformed into code (software) to be affective' (Galloway 
2002). Galloway continues discussing the difference between code and text in the following way:

How can code be so different than mere writing? The answer to this lies in the unique nature of computer code. It lies not in the fact that code is sub-linguistic, but rather that it is hyperlinguistic. Code is a language, but a very special kind of language. Code is the only language that is executable. As Kittler has pointed out, '[t]here exists no word in any ordinary language which does what it says. No description of a machine sets the machine into motion.' (Ibid.)

It is my hypothesis here that this relation between text and code can be transposed to the relation between image and style. So that style (and now I paraphrase the following paragraph in Galloway's text) is an image of a second order that actually does what it shows - it is a machine for converting meaning into action. Style has a visual meaning, but it is foremost an enactment of meaning. Thus, while images such as Madonna and Child, Reclining Nude or Untitled only have a visual state, style has both a visual state and an executable state. In this way, style is the summation of images plus an executable meta-layer that encapsulates that visuality.

Count Panza was an early mover in collecting conceptual and minimal art, and even if supportive of the above-mentioned critical potential of the artistic practices, he nevertheless wanted to defend his investment by having the artist to sign a legal statement, saying: 'I certify that the above work is my original and unique creation, and I undertake not to do, realize, sell, or authorize the same work' (Hapgood 1990: 116, quoting Knight 1987: 184, 
$219,243)$. Now, in an artistic context where the work is not a production of an image in a certain style, but the execution of an identifiable style as the code of the author, the precision of this legal statement is not very high, as the phrase 'the same work' turns out to be quite void of precision given the distributive character of the stylistic identity of the modern artist. Is the work an image or a style? An idea or the material? Would yet another drip-painting qualify as 'the same work'. Would an execution of one of Lawrence Weiner's pieces qualify as 'the same work' as another execution of the piece? This is because there is no such thing as 'originality' or 'uniqueness' in the execution of a style as in the execution of code. Style and code only exist when executed, that is, when copied and actualised, re-enacted and iterated.

Count Panza's legal approach to his acquisitions did backfire when he wanted to sell his collection. Donald Judd and Carl André both denounced exhibited refabrications of their works by Count Panza as 'fakes', insisting on the supervision of the artist in any refabrication of a piece or relocation of any site-specific work (Hapgood 1990: 120). Thus, even though Judd's and André's works are obviously algorithmic in character, they would under no circumstance approve to Lawrence Weiner's Statement of Intent that the piece may be fabricated by anyone or that the piece need not to be built. Only the artist may perform the piece as only the artist can guarantee the integrity of every aspect of the piece. In a letter to the editors of Art in America, Judd described one piece refabricated as: 'its appearance was not mine: the galvanized surface was wrong and the details were wrong. I remember that three narrow panels ineptly made the left corner' (Judd 1990: 33). In a similar letter Carl André didn’t specify what was wrong, just that it was wrong: 'No such "refabrication” of my work has been authorized by me and any such "refabrication" is a gross falsification of my work' (André 1990: 31). 
Judd and André thus state that their works are not algorithms or scores, which can be performed or refabricated, but 'classical' sculptural originals carrying with them the unique sensibility of the artist in material and handling. This is obviously not the case aesthetically speaking. I believe Judd and André here, at best, are fooling themselves. Nothing but legal actions hinder anyone from making 'a Judd' or 'an André' - as little as anyone performing a piece by John Cage. Not even skill is needed. Judd and André are here confusing themselves as individuals with an author function.

Most other artists have taken another stance on the question of copying and refabrication. Even though paying lip service to the idea of originality and authenticity of the work for to protect the collector's investment, Sol LeWitt did not consider any unauthorized use of his instructions for a wall drawing to be unethical. Instead, he would consider it a compliment. Robert Morris has taken a similar position as LeWitt and doesn't seem to care much about the issues of originals or unique works (Hapgood 1990: 120-121). The argument for both is that you can't own ideas, only physical objects, and correspondingly that you can't own a style, only a physical embodiment as an example of a style.

When style was a historical subconscious or a normative concept, style was that, which should be copied. The symbolical value of art was primarily measured in the attribution to a remembered name, 'a Rafael', 'a Rembrandt', 'a Corot', with correspondingly lesser values linked to attributions like 'a copy of Rafael', 'in the style of Rembrandt', or 'circle of Corot' - denominations that don't make sense at all in modern or contemporary art. What would an attribution like 'in the style of Pollock' or 'circle of Polke' mean? When style starts to be a symbolical value, intrinsically linked to an author function through a sort of performative signature code, a software (the algorithmic performative act of the artist) producing a hardware, which can't be referenced through any concept of subject matter, skill or quality, then what is copied is nothing but the author function as such, that is: the 
algorithmic performative act. And this has been the great taboo in art since the late 19th century. It must not be copied. On the other hand, as a concept of style as code, it must (as any style or code) be copied, else it would cease to exist - style or code being entities whose existence is defined by their continuous executions and re-enactments, images which primarily exists in an executable state.

The image of a second order is thus a superposition of a series of antinomic concepts. It is the superposition of representation with code or algorithm, the superposition of the chronotopological index with the transhistorical image, and the superposition of an author function with the anonymity of style.

Compared to the negotiations of appropriation art or the more-or-less established artists' remakings and paraphrases of modern classics, like Marcel Duchamp's Fountain or Robert Morris' Mirrored Cube, all of which are well known strategies during the past decades, but which rather strengthen the author function of art works than challenge it, works like the 'anonymous plagiarism' of Kirkeby's brick code, confusing the logic of art from an adjacent discourse, is a more potent and threatening challenge to the authority of art, as it makes our complex system of art unstable and collapses the antinomical superpositions the system of fine art is constructed on antinomical structures which were first recognised with the emergence of the production logic of minimal art and becoming even more insistent with the 'inclusive' concept of art of recent years. 


\section{References}

André, Carl (1990), ‘Artist Disowns “Refabricated” Work', Art in America, 78 (3): 31.

Belting, Hans (1991), Bild und Kult. Eine Geschichte des Bildes vor dem Zeitalter der Kunst, München: C.H. Beck.

Boime, Albert (1964), 'La Musée des Copies', Gazette des beaux-arts, 64: 237.

Clair, Jean (1988), Paradoxe sur le conservateur précédé de De la modernité conçue comme une religion, Paris: L’Échoppe.

Darr, Alan, Peter Barnet, and Antonia Boström, eds. (2002), Catalogue of Italian Sculpture in the Detroit Institute of Arts, Detroit: The Detroit Institute of Arts and Harvey Miller Publishers.

Foucault, Michel (1984), 'What Is an Author?', in Paul Rabinow (ed.), The Foucault Reader, ed. Paul Rabinow, 101-120, New York: Pantheon Books.

Galloway, Alexander. 'How We Made Our Own "Carnivore", rhizome.org. 20 Jun 2002, http://rhizome.org/discuss/view/2654/.

Hapgood, Susan (1990), 'Remaking Art History', Art in America, 78 (3): 115-123.

Judd, Donald (1990), ‘Artist Disowns “Copied” Sculpture', Art in America, 78 (4): 33.

Knight, Christopher (1987), Art of the Sixties and Seventies: The Panza Collection, New York: Rizzoli.

Kuspit, Donald (2004), The End of Art, Cambridge: Cambridge University Press.

Lenain, Thierry (2007), 'Perfect Fakes and the Modern Religion of Authenticity', in Victor I. Stoichita (ed.), Das Double, 47-58, Wolfenbüttel: Harrassowitz.

Lenain, Thierry (2011), Art Forgery. The History of a Modern Obsession, London: Reaktion Books.

LeWitt, Sol (1999), 'Paragraphs on Conceptual Art', in Alexander Alberro and Blake Stimson (eds.), Conceptual Art: A Critical Anthology, 12-16, Cambridge, MA: MIT Press. 
Manovich, Lev (2001), 'The Database', in The Language of New Media, 218-243, Cambridge, MA: MIT Press (originally published online in 1999 as 'Database as a Symbolic Form', http://manovich.net/index.php/projects/database-as-a-symbolicform).

Moskowitz, Anita F. (2004), 'The Case of Giovanni Bastianini: A Fair and Balanced View', Artibus et historiae, 25 (50): 157-185.

Moskowitz, Anita F. (2006), 'The Case of Giovanni Bastianini. II. A Hung Jury?', Artibus et historiae, 27 (54): 201-217.

Nagel, Alexander (2004), 'The Copy and Its Evil Twin: Thirteen Notes on Forgery', Cabinet, 14: $102-105$.

Siegelaub, Seth (1969), January 5-31, 1969, New York, 1969.

Sox, David (1987), Unmasking the Forger. The Dossena Deception, London: Unwin Hyman.

Warren, Jeremy (2005), 'Forgery in Risorgimento Florence. Bastianini’s “Giovanni delle Bande Nere" in the Wallace Collection', Burlington Magazine, 147 (1232): 729-741. 